\title{
PROGRESIVITAS PUTUSAN PEMIDANAAN TERHADAP KORPORASI PELAKU TINDAK PIDANA KORUPSI \\ (Progressivity of Criminal Decision on Corporate Actors Corruption)
}

\author{
Budi Suhariyanto \\ Pusat Penelitian dan Pengembangan Hukum dan Peradilan MA-RI \\ Jl. Jend. A. Yani Kav.58 Cempaka Putih Timur Jakarta. \\ Email: penelitihukumma@gmail.com
}

Tulisan diterima 12-2-2016, Revisi 8-6-2016, Disetujui diterbitkan 21-6-2016

\begin{abstract}
Normatively corporation has long been established as a legal subject perpetrators of corruption that can be prosecuted and decided. However, only one case of corruption that makes the corporation as a defendant and the punishment meted out to them is through the decisionNo.04/PID.SUS/ 2011 /PT.BJM. There is a rule of law in the consideration of this decision which confirms the correlation between punishment rudimentary calculation simposed on managers who incidentally had been convicted and sentenced by a court sentencing inkracht with the calculation of fines to beborne by the corporation. Rule of law is a progressive discovery of the law because it contains novelty and can be used as a reference in corporate penalize the perpetrators of corruption by the other judge at a later date.
\end{abstract}

Keywords: Progressivity, Punishment Decision, Corporations, Corruption

\begin{abstract}
ABSTRAK
Secara normatif korporasi telah lama ditetapkan sebagai subjek hukum pelaku tindak pidana korupsi sehingga bisa dituntut dan diputuskan pemidanaannya. Namun baru satu perkara korupsi yang menjadikan korporasi sebagai terdakwa dan dijatuhkan pemidanaan terhadapnya yaitu melalui putusan No.04/PID.SUS/2011/ PT.BJM. Terdapat kaidah hukum dalam pertimbangan putusan ini yaitu menegaskan korelasi antara perhitungan pemidanaan yang belum sempurna dijatuhkan kepada pengurusnya yang notabene telah dinyatakan bersalah dan dijatuhi pemidanaan oleh pengadilan yang inkracht dengan penghitungan denda yang harus ditanggung oleh korporasinya. Kaidah hukum ini merupakan penemuan hukum progresif karena mengandung kebaruan dan dapat digunakan sebagai acuan dalam mempidana korporasi pelaku tindak pidana korupsi oleh para Hakim lainnya di kemudian hari.
\end{abstract}

Kata Kunci: Progresivitas, Putusan Pemidanaan, Korporasi, Korupsi

\section{PENDAHULUAN}

Kebanyakan negara di dunia pernah dilanda masalah korupsi, dan bahkan hingga sekarang masih merebak. Begitu pula dengan Indonesia, korupsi sudah melanda negeri ini sejak lama dan hampir menyentuh semua lini kehidupan masyarakat (Effendy, 2012:3). Korupsi ada dan tumbuh seiring laju peradaban manusia. Korupsi muncul karena laku manusia yang menyimpang akibat syahwat materi yang tak pernah terpuaskan, menyebabkan korupsi susah untuk diberantas. Tidak seperti kejahatan konvensional, korupsi adalah kejahatan yang berkembang secara dinamis dari waktu ke waktu. Karena bergerak secara dinamis, penegakan hukum dalam pemberantasannya tidak bisa hanya dengan mengandalkan cara-cara konvensional (Mas, 2014:v). Berbagai terobosan baik dalam lingkup kebijakan legislasi maupun penegakan hukum serta putusan Hakim yang progresif harus selalu diupayakan.

Salah satu terobosan kebijakan hukum pidana terkini dalam pemberantasan tindak pidana korupsi adalah dengan menjadikan korporasi sebagai salah satu subjek hukumnya sehingga bisa dituntut pertanggungjawaban pidana serta dapat diputuskan pemidanaan terhadapnya. Jika sebelumnya subyek hukum tindak pidana korupsi hanya terkait dengan orang yang mana lebih khusus lagi terkait dengan pegawai negeri (vide Pasal 2 Undang-Undang Nomor 3 Tahun 1971 tentang Pemberantasan Tindak Pidana Korupsi), saat ini pengertian orang tersebut tidak semata 
diartikan sebagai manusia tetapi juga meliputi korporasi (vide Pasal 1 angka 3 Undang-Undang Nomor 31 tahun 1999 Jo. Undang-Undang Nomor 20 Tahun 2001 tentang Pemberantasan Tindak Pidana Korupsi (UU PTPK)). Kebijakan memperluas subjek hukum tindak pidana korupsi pada korporasi ini merupakan bagian dari strategi pemberantasan dan penanggulangan tindak pidana korupsi.

Kebijakan perundang-undangan mengadakan perluasan subjek tindak pidana korupsi yang meliputi korporasi, bukan tanpa alasan. Latar belakang ditempuhnya kebijakan untuk mengadakan perluasan adalah, bahwa perilaku koruptif yang merugikan keuangan dan perkonomian negara, ternyata tidak hanya dilakukan oleh mereka-mereka yang memenuhi kualifikasipegawainegerimenurutundang-undang kepegawaian saja. Mereka-mereka yang bukan pegawai negeri dalam pengertian undang-undang kepegawaian, yang menerima tugas tertentu dari suatu badan negara, atau badan atau korporasi yang menerima bantuan dari negara, ternyata dapat pula melakukan perbuatan tercela yang merugikan keuangan negara atau perekonomian negara. Demikian pula halnya dengan korporasi, yang diyakini dan diprediksi memiliki potensi melakukan tindak pidana (Danil, 2012:110).

Pada dasarnya proses penegakan hukum terhadap tindak pidana yang dilakukan oleh korporasi akan dihadapkan pada 2 (dua) masalah pokok yaitu masalah pertanggungjawaban pidana dari lembaga sebagai korporasi dan sistem pemidanaan terhadap lembaga sebagai korporasi. Kedua masalah inibelum diatur secara eksplisit dalam perundang-undangan, namun karena secara fisik kegiatan korporasi diwakili oleh satu atau beberapa eksekutif korporasi maka secara teoritis bila korporasi melakukan kegiatan kejahatan adalah manifestasi dari para eksekutifnya. Demikian pula sistem pemidanaannya, sulit untuk menentukan sanksi pidana yang tepat untuk korporasi (Effendy, 2012:110). Apalagi dalam konteks penjatuhan putusan pemidanaan terhadap korporasi yang merupakan pelaku tindak pidana korupsi tentu akan mengalami kesulitan dan tantangan tersendiri. Tidak mudah bagi aparat penegak hukum dalam menetapkan korporasi sebagai subyek hukum pelaku tindak pidana korupsi dan oleh Hakim berhasil dijatuhi putusan pemidanaan. Kalaupun ada berarti merupakan hal baru dan dapat dikategorikan sebagai sebuah langkah penegakan hukum yang progresif.

Sejauh ini baru satu perkara korporasi sebagai pelaku tindak pidana korupsi yang didakwa dan dituntut serta diputuskan pemidanaannya hingga berkekuatan hukum tetap yaitu PT. GIRI JALADHI WANA (PT GJW). Dalam tuntutannya Jaksa Penuntut Umum (JPU), menuntut agar PT GJW dinyatakan telah terbukti bersalah melanggar Pasal 2 ayat (1) jo. Pasal 18 Jo. Pasal 20 UU PTPK jo. Pasal 64 ayat (1) KUHP sebagaimana dalam Dakwaan Primair, dan menjatuhkan pidana terhadap terdakwa PT GJW dengan pidana denda sebesar Rp.1.300.000.000,(satu milyar tiga ratus juta rupiah) serta pidana tambahan tambahan berupa penutupan sementara PT.GJW selama 6 (enam) bulan.Atas tuntutan tersebut, Majelis Hakim Pengadilan Negeri Banjarmasin melalui Putusannya No.812/Pid .Sus /2010/PN.Bjm memutuskan persis sama dengan tuntutan JPU. Atas putusan Pengadilan Negeri Banjarmasin, terdakwa melalui Penasihat hukumnya mengajukan upaya hukum banding kepada Pengadilan Tinggi Banjarmasin.

Pengadilan Tnggi Banjarmasin melalui putusannya Nomor 04/PID.SUS/201 1/PT.BJM memutuskan menerima permintaan banding dari Penasehat Hukum Terdakwa dan menguatkan Putusan Pengadilan Negeri Banjarmasin Nomor : 812/Pid .Sus /2010 /PN.Bjm tanggal 09 Juni 2011 yang dimintakan banding tersebut, dengan perbaikan sekedar mengenai besarnya denda sehingga untuk selengkapnya berbunyi menyatakan terdakwa PT GJW telah terbukti secara sah dan meyakinkan bersalah melakukan tindak pidana "korupsi secara berlanjut" dan karenanya menjatuhkan kepada terdakwa PT GJW pidana denda sebesar Rp.1.317 .782 .129,(satu milyar tiga ratus tujuh belas juta tujuh ratus delapan puluh dua ribu seratus dua puluh sembilan Rupiah) serta menjatuhkan pidana tambahan berupa Penutupan Sementara PT.GIRI JALADHI WANA selama 6 (enam) bulan.

Putusan pemidanaan dalam kedua putusan pengadilan tersebut di atas merupakan angin segar bagi pemberantasan korupsi di negeri ini. Kedua putusan ini akan menjadi pionir dan inspirasi bagi para penegak hukum di bidang tindak pidana korupsi pada umumnya dan khususnya bagi kalangan Hakim saat berhadapan dengan perkara korupsi dengan pelaku atau terdakwanya 


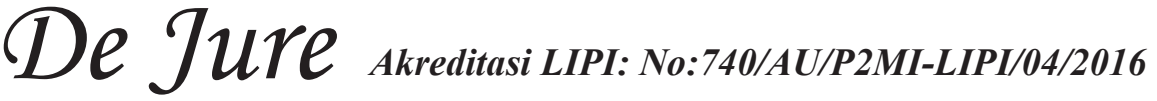

adalah korporasi. Berdasarkan pertimbangan hukum yang ada intinya menyebutkan bahwa apabila tindak pidana korupsi dilakukan atau diperintahkan oleh personil yang memiliki directing mind dan merupakan perbuatan intra vires yaitu sesuai dengan maksud dan tujuan korporasi maka perbuatan pengurusnya dapat dibebankan pertanggungjawabannya kepada korporasi karenanya layak untuk dijatuhkan putusan pemidanaan yang sesuai dengan tuntutan JPU (vide Putusan No.812/Pid .Sus /2010 / PN.Bjm). Dengan pertimbangan yang demikian dapat dikatakan bahwa putusan pemidanaan yang dijatuhkan pada korporasi sebagai pelaku tindak pidana korupsi tersebut memiliki nilai progresivitas hukum.

Bahkan dengan bentuk penambahan sanksi pidana denda oleh putusannya Nomor 04/PID. SUS/201 1/PT.BJMyang melebihi tuntutan JPU dan secara teknis mengelaborasi dari kekurangan putusan pidana uang pengganti yang notabene sudah pernah dijatuhkan terlebih dahulu dari putusan pemidanaan terhadap Direktur Utamanya (vide putusan Nomor : 908/Pid.B/2008 /PN.Bjm jo putusan Nomor : 02/Pid .Sus /2009/PT.BJM jo. putusan Nomor : 936.K/Pid .Sus /2009) sudah tentu merupakan putusan yang progresifjuga. Oleh karenanya putusan pemidanaan terhadap PT GJW ini menarik untuk dikaji nilai progresivitasnya. Dengan demikian dapat dijadikan permasalahan yaitu bagaimanakah eksistensi sistem pemidanaan terhadap korporasi pelaku tindak pidana korupsi ? dan bagaimanakah putusan pemidanaan terhadap korporasi pelaku tindak pidana korupsi ditinjau dari perspektif hukum progresif?

\section{METODE PENELITIAN}

Metode yuridis normatif digunakan dalam melakukan pengkajian putusan pemidanaan terhadap korporasi pelaku tindak pidana korupsi dalam perspektif hukum progresif ini. Terdapat 3 (tiga) pendekatan untuk mengkaji permasalahan yaitu pendekatan perundang-undangan (statute approach)dan pendekatan kasus (case approach) serta pendekatan konseptual (conseptual approach). Pendekatan perundang-undangan digunakan untuk mengkaji masalah secara normatif baik dari perspektif ius constitutum maupun ius constituendum. Pendekatan kasus digunakan untuk mengkaji masalah dari segi praktek peradilan yang berkembang dalam merespon dan mengaktualisasikan hukum secara in concreto. Pendekatan konseptual digunakan untuk mengkaji masalah pemidanaan korporasi dalam pertimbangan hukum yang tercantum pada putusan pengadilan dihubungkan dengan pandangan dan doktrin-doktrin ahli hukum (Panggabean, 2014, hal.170).

Adapun sumber data yang digunakan adalah data sekunder yang terdiri atas bahan hukum primer berupa peraturan perundang-undangan dan putusan pengadilan serta bahan hukum sekunder berupa literatur dan hasil penelitian. Peraturan perundang-undangan yang digunakan antara lain yang berkaitan dengan pengaturan tentang korporasi sebagai subjek hukum pidana dan tindak pidana korupsiyaitu Undang-Undang Nomor 31 Tahun 1999 jo. Undang-Undang Nomor 20 Tahun 2001 tentang Pemberantasan Tindak Pidana Korupsi. Putusan pengadilan yang dikaji adalah yang terkait dengan perkara korporasi Pelaku tindak pidana korupsiyaitu Putusan No.812/ Pid .Sus /2010/PN.Bjmdan putusanNomor 04/PID.SUS/201 1/PT.BJMyang diasumsikan mengandung penemuan kaidah hukum baru ditinjau dari perspektif hukum progresif.

Adapunliteraturyang digunakan dalam kajian agar terhindar dari kekeliruan pandangan adalah yang berkaitan dengan pemidanaan, korporasi, tindak pidana korupsi, dan teori penemuan hukum, serta metode penemuan hukum progresif. Bahanbahan hukum dan literatur tersebut dikumpulkan melalui metode sistematis dan dicatat dalam kartu antara lain permasalahannya, asas-asas, argumentasi, implementasi yang ditempuh, alternatif pemecahannya dan lain sebagainya. Data yang telah dikumpulkan kemudian dideskripsikan dan diinterpretasikan sesuai pokok permasalahan selanjutnya disistematisasi, dieksplanasi, dan diberikan argumentasi. Metode analisis yang diterapkan untuk mendapatkan kesimpulan atas permasalahan yang dibahas adalah melalui analisis yuridis kualitatif.

\section{PEMBAHASAN}

\section{A. Eksistensi Sistem Pemidanaan Terhadap Korporasi Pelaku Tindak Pidana Korupsi}

Secara umum kejahatan korporasi memiliki karakteristik yang sangat berbeda dengan 
kejahatan yang bersifat konvensional, diantaranya (Budianto, 2012:57):

1. Kejahatan tersebut sulit dilihat (low visibility), karena biasanya tertutup oleh kegiatan pekerjaan yang normal dan rutin, melibatkan keahlian profesional dan sistem organisasi yang kompleks;

2. Kejahatan tersebut sangat kompleks (complesity) karena selalu berkaitan dengan kebohongan, penipuan dan pencurian serta seringkali berkaitan dengan sebuah yang ilmiah, teknologis, finansial, legal, terorganisasikan, dan melibatkan banyak orang serta berjalan bertahun-tahun;

3. Terjadinya penyebaran tanggungjawab (diffusion of respnsibility) yang semakin luas akibat komplesitas organisasi;

4. Penyebaran korban yang sangat luas (diffusion of victimization) seperti polusi dan penipuan;

5. Hambatan dalam pendeteksian dan penuntutan (detection and prosecution) sebagai akibat profesionalisme yang tidak seimbang antara aparat penegak hukum degan pelaku kejahatan;

6. Peraturan yang tidak jelas (ambiguitas law) yang sering menimbulkan kerugian dalam penegakan hukum;

7. Sikap mendua status pelaku tindak pidana. harus diakui bahwa pelaku tindak pidana pada umumnya tidak melanggar peraturan perundang-undangan, tetapi memang perbuatan tersebut illegal.

Berdasarkan kerakteristik di atas, kejahatan korporasi seringkali diidentikkan dengan kejahatan kerah-putih (white collar crime), dan kejahatan sepertiini menurut Steven Box seringkali diabaikan keberadaannya oleh masyarakat dikarenakan:

1. Kejahatan korporasi seringkali tidak nampak karena sifatnya yang kompleks dan direncanakan dengan halus;

2. Ketiadaan dan kelemahan penegak hukum serta sanksi sosial yang lunak menunjukkan tidak jelasnya batas-batas moral dalam kejahatan korporasi;

3. Media massa yang seharusnya berfungsi sebagai sarana kontrol sosial malah banyak yang tidak mengungkapkan dan memaparkannya;

4. Pandangan sebagian besar kriminolog yang kurang memperhatikan kajiannya terhadap white coloor crime dan menganggap kejahatan konvensional lebih berbahaya (Effendy, 2012:94).

Pada asasnya yang dapat melakukan tindak pidana adalah manusia (naturlijk persoon). Hal ini dapat disimpulkan dari rumusan tindak pidana dalam undang-undang yang selalu dimulai dengan kata "barangsiapa" yang tidak dapat diartikan lain selain orang (manusia). Di samping itu, yang dapat dipertanggungjawabkan dalam hukum pidana adalah manusia. Hal itu disebabkan karena kesalahan, baik dalam bentuk kesengajaan maupun kealpaan merupakan sikap dalam batin manusia. Atas dasar pemikiran seperti itu pulalah, maka dalam penjelasan KUHP (Memorie van Toelichting), yaitu penjelasan atas Pasal 59 KUHP ditegaskan bahwa, suatu tindak pidana hanya dapat dilakukan oleh manusia. (Danil, 2012:104).

Sangat sulit menetapkan kesalahan pada korporasi karena yang dapat melakukan kesalahan itu hanyalah manusia (Toruan, 2014:415). la tidak memiliki jiwa dan karena itu sulit untuk mengetahui niat serta mengukur kedewasaannya. Namun, apabila korporasi tidak dapat dimintai pertanggungjawaban hanya karena sulitnya membuktikan kesalahan, maka akan terjadi impunity terhadap korporasi, padahal korporasi juga banyak melakukan tindak pidana. Banyaknya kasus-kasus yang melibatkan korporasi dan belum adanya aturan tegas yang menyatakan korporsi sebagai subjek hukum pidana dan bentuk hukuman bagi korporasi, menjadikan korporasi melalui pengurus-pengurusnya leluasa melakukan tindak pidana tanpa adanya pencegahan dari manapun(Sintung, 2015:201)

Saat ini telah diakomodasi pertanggungjawaban pidana selain manusia (persoon), yaitu korporasi (recht persoon). Terdapat beberapa teori dan banyak diadopsi sebagai teori yang digunakan untuk menilai pertanggungjawaban pidana korporasi, yaitu: Pertama, doktrin pertanggungjawaban pidana yang ketat menurut undang-undang (strict liability), jadi pertanggungjawaban korporasi semata-mata berdasarkan bunyi undang-undang dengan tanpa memandang siapa yang melakukan 


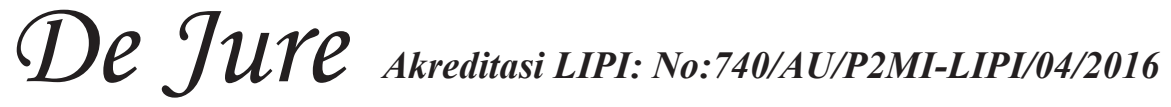

kesalahan. Kedua, doktrin pertanggungjawaban pengganti (vicarious liability), yang lebih menekankan pada pertanggungjawaban oleh pengurus korporasi sebagai"agen" perbuatan dari korporasi tersebut. Ketiga, teori identifikasi (direct corporate criminal liability) atau doktrin pertanggungjawaban pidana secara langsung yaitu perusahaan dapat melakukan sejumlah delik secara langsung melalui orang-orang yang berhubungan erat dengan perusahaan dan dipandang sebagai perusahaan itu sendiri. Keempat, teori agregasi yang menyatakan bahwa pertanggungjawaban pidana dapat dibebankan kepada badan hukum jika perbuatan tersebut dilakukan oleh sejumlah orang yang memenuhi unsur delik yang mana antara satu dengan yang lain saling terkait dan bukan berdiri sendiri-sendiri. Kelima, ajaran corporate culture model atau model budaya kerja yaitu ajaran yang memfokuskan pada kebijakan badan hukum yang tersurat dan tersirat mempengaruhi cara kerja badan hukum tersebut. badan hukum dapat dipertanggungjawabkan secara pidana apabila tindakan seseorang memiliki dasar yang rasional bahwa badan hukum tersebut memberikan wewenang atau mengizinkan perbuatan tersebut dilakukan (Hiariej, 2014:165-166)

Berdasarkan doktrin-doktrin pertanggungjawaban pidana korporasi, korporasi dinilai sudah layak untuk ditetapkan sebagai subjek hukum pidana dan ditentukan takaran pemidanaannya secara normatf. Penetapan korporasi sebagai subjek tindak pidana dalam peraturan perundangundangan di Indonesia, terdapat dan diatur di luar KUHP. Pengaturan korporasi sebagai subjek tindak pidana pada dasarnya dapat digolongkan dalam dua kategori pengaturan, yaitu (Priyatno, 2004:163-166):

a. Yang menyatakan korporasi sebagai subjek tindak pidana, akan tetapi pertanggungjawaban pidananya dibebankan terhadap anggota atau pengurus korporasi. Adapun ketentuan-ketentuan peraturan perundang-undangan menurut kategori pertama antara lain terdapat dalam:

1) Pasal 19 Undang-Undang Nomor 1 Tahun 1951 tentang Pernyataan Berlakunya Undang-Undang Kerja Tahun 1948 Nomor 12 dari RI untuk seluruh Indonesia;

2) Pasal 30 Undang-Undang Nomor 2 Tahun 1951 tentang Pernyataan
Berlakunya Undang-Undang Kecelakaan 1947 Nomor 43 RI untuk seluruh Indonesia;

3) Pasal 7 Undang-Undang Nomor 3 Tahun 1951 tentang Pernyataan Berlakunya Undang-Undang Pengawasan Perburuhan Tahun 1948 Nomo 23 dari RI untuk seluruh Indonesia;

4) Pasal 4 Undang-Undang Nomor 12 Drt Tahun 1951 tentang Senjata Api;

5) Pasal 3 ayat (2) dan ayat (3) UndangUndang Nomor 3 Tahun 1953 tentang Pembukaan Apotik

6) Pasal 34 Undang-Undang Nomor 2 Tahun 1981 tentang Metrologi Legal;

7) Pasal 35 Undang-Undang Nomor 3 Tahun 1982 Wajib Daftar Perusahaan;

8) Pasal 46 ayat (2) Undang-Undang Nomor 7 Tahun 1992 Jo. UndangUndang Nomor 10 Tahun 1998 tentang Perbankan.

b. Yang menyatakan korporasi sebagai subjek tindak pidana dan secara tegas dapat dipertanggungjawabkan pidana secara langsung. Peraturan perundang-undangan yang menempatkan korporasi sebagai subjek tindak pidana dan secara langsung dapat dipertanggungjawabkan secara pidana, antara lain diatur dalam:

1) Pasal 15 ayat (1) Undang-Undang Nomor 7 Drt Tahun 1955 tentang Pengusutan, Penuntutan dan Peradilan Tindak Pidana Ekonomi;

2) Pasal 1angka 13, Pasal 43, Pasal 44, Pasal 45, Pasal 46 dan Pasal 47 UndangUndang Nomor 38 Tahun 2009 tentang Pos;

3) Pasal 20 ayat (1) Undang-Undang Nomor 31 Tahun 1999 jo. UndangUndang Nomor 20 Tahun 2001 tentang Pemberantasan Tindak Pidana Korupsi;

4) Pasal 1 angka 9 dan Pasal 6 UndangUndang Nomor 8 Tahun 2010 tentang Pencegahan dan Pemberantasan Tindak Pidana Pencucian Uang

Ditinjau dari perspektif politik hukum pidana, penempatan korporasi sebagai subjek tindak pidana semata tanpa diatur mengenai kapan dikatakan korporasi melakukan tindak 
pidana dan dalam hal bagaimana korporasi dapat dipertanggungjawabkan secara pidana, secara teoritis dan praktis menurut Priyatno dalam penegakan hukumnya tidak dapat dilaksanakan. Sehingga usaha penanggulangan dengan hukum pidana tidak dapat berjalan dengan baik. Sebagai contoh adanya kelemahan dalam kebijakan legislasi terhadap sanksi pidana korporasi, yaitu tidak adanya ketentuan khusus mengenai sanksi pidana bagi korporasi untuk delik yang hanya diancamkan dengan pidana penjara, dan tidak adanya aturan tentang pidana pengganti apabila denda tidak dibayarkan oleh korporasi. Kelemahan-kelemahan tersebut dalam rangka pembaruan hukum pidana, harus diperbaharui (Priyatno, 2004:152-153).

Khusus pada korporasi sebagai subjek tindak pidanakorupsimempunyaimasalahyangkompleks dalam hal penerapan pertanggungjawaban pidananya. Apalagi mengingat korupsi tidak hanya dikategorikan sebagai kejahatan kerah putih (white collor crime) saja, tetapi juga dikategori sebagai tindak pidana yang terorganisir (organized crime). Dalam konteks korupsi, modus operandi yang halus dan canggih serta terorganisir sangat memungkinkan terjadi melalui sebuah korporasi sebagai sarananya sehingga menjadikan pembuktian dan pertanggungjawaban pidananya cukup sulit. Apalagi jika tidak ada payung hukum yang bisa menjerat dan memberikan kewenangan kepada penegak hukum untuk menindak dan melakukan pemidanaan terhadapnya.

Instrumen hukum internasional di bidang pemberantasan korupsi yaitu The United Nations Convention Against Corruption (UNCAC) memberikan arah pengaturan terhadap korporasi yang dinilai dapat melakukan tindak pidana korupsi yaitu dalam article 12 Private Sector angka 1 yang menyebutkan bahwa Each State Party shall take measures, in accordance with the fundamental principles of its domestic law, to prevent corruption involving the private sector, enhance accounting and auditing standards in the private sector and, where appropriate, provide affective, proportionate and dissuasive civil, administrative or criminal penalties for failure to comply with such measures.Kemudian dalam article 26 Liability of Legal Persons disebutkan secara rinci bahwa:

\section{Each State Party shall adopt such measures} as may be necessary, consistent with its legal principles, to establish the liability of legal persons for participation in the offences established in accodance with Coventions;

2. Subject to the legal prinsciples of the State Party, the liability of legal persons may be criminal, civil or administrative;

3. Such liability shall be without prejudice to the criminal liability of natural persons who have commited the offences;

4. Each State Party shall, in particular, ensure the legal persons held liable in accordance with this article are subject to effective, propotionate and dissuasive criminal or non-criminal sanctions, including monetary sanctions.

Pada intinya ketentuan-ketentuan dari UNCAC di atas menghendaki Negara Pihak wajib mengambil tindakan-tindakan, sesuai dengan prinsip-prinsip dasar hukum internalya, untuk mencegah korupsi yang melibatkan korporasi, meningkatkan standar akuntansi dan audit di sektor swasta, dan jika dipandang perlu memberikan sanksi perdata, administrasi atau pidana yang efektif, proporsional dan bersifat larangan bagi yang tidak mematuhi tindakan-tindakan tersebut. Karenanya Negara Pihak wajib menetapkan tanggungjawab korporasi yang berpatisipasi dalam kejahatan korupsi. Pertanggungjawaban tersebut dapat bersifat pidana, perdata atau administratif. Tanggungjawab tersebut tidak mengurangi tanggungjawab pidana orang perorangan yang melakukan kejahatan. Negara Pihak juga wajib mengusahakan agar korporasi yang bertanggungjawab tersebut dikenakan sanksi pidana atau non-pidana yang efektif, proporsional dan bersifat larangan, termasuk sanksi keuangan.

Indonesia sebagai salah satu Negara Pihak telah melakukan rativikasi dari UNCAC yaitu dengan menerbitkan Undang-Undang Nomor 7 Tahun 2006. Beberapa inti pengaturan dari article di atas sesungguhnya sebagiannya sudah diakomodasi oleh UU PTPK terkait dengan pertanggungjawaban pidana dan sistem pemidanaan terhadap korporasi yang melakukan korupsi. Pasal 1 angka 3 UU PTPK menegaskan bahwa yang dimaksudkan oleh "setiap orang" adalah "orang perseorangan" atau termasuk "korporasi". Adapun yang dimaksudkan dengan korporasi adalah kumpulan orang dan atau kekayaan yang terorganisasi baik merupakanbadan 


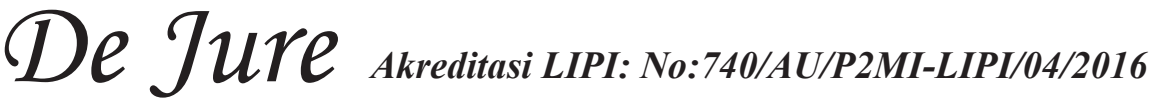

hukum maupun bukan badan hukum(vide Pasal 1 angka 1 UU PTPK). Dalam konteks ini korporasi telah dijadikan sebagai salah satu subjek hukum yang dapat dituntut pertanggungjawabannya saat melakukan tindak pidana korupsi.

Adapun mekanisme pertanggungjawaban dan sistem pemidanaannya diatur secara rinci yaitu dalam hal tindak pidana korupsi dilakukan oleh atau atas nama suatu korporasi, maka tuntutan dan penjatuhan pidana dapat dilakukan terhadap korporasi dan atau pengurusnya (vide Pasal 20 ayat (1) UU PTPK). Artinya secara komulatif-alternatif dapat dituntut dan diputus pemidanaannya bilamana dilakukan oleh atau atas nama suatu korporasi sehingga dapat dilakukan terhadap "korporasi dan pengurus" atau terhadap "korporasi" saja atau "pengurus" saja. Selanjutnya untuk mengidentifikasi bahwa tindak pidana korupsi dilakukan oleh korporasi adalah apabila tindak pidana tersebut dilakukan oleh orang-orang baik berdasarkan hubungan kerja maupun berdasarkan hubungan lain, bertindak dalam lingkungan korporasi tersebut baik sendiri maupun bersama-sama (vide Pasal 20 ayat (2) UU PTPK).

Secara teknis dalam hal tuntutan pidana dilakukanterhadapsuatukorporasi, makakorporasi tersebut diwakili oleh pengurus. Pengurus yang mewakili korporasi dapat diwakili oleh orang lain (vide Pasal 20 ayat (3) jo Pasal 20 ayat (4) UU PTPK). Meskipun demikian Hakim dapat memerintahkan agar pengurus korporasi tersebut menghadap sendiri pada pemeriksaan disidang pengadilan dan dapat pula hakim memerintahkan agar pengurus yang dimaksud dibawa ke sidang pengadilan (vide Pasal 20 ayat (5) UU PTPK).

Dalam hal tuntutan pidana dilakukan terhadap korporasi, maka panggilan untuk menghadap dan penyerahan surat panggilan tersebut disampaikan kepada pengurus di tempat tinggal pengurus atau di tempat pengurus berkantor. Pidana pokok yang dapat dijatuhkan terhadap korporasi hanya pidana denda, dengan ketentuan maksimum pidana ditambah sepertiga (vide Pasal 20 ayat (6) dan ayat (7) UU PTPK).

\section{B. Putusan Pemidanaan Terhadap Korporasi Pelaku Tindak Pidana Korupsi Ditinjau Dari Perspektif Hukum Progresif}

Meskipun telah ditegaskan secara normatif bahwa korporasi adalah salah satu subjek hukum dan dapat dipertanggungjawabkan dalam tindak pidana korupsi sejak tahun 1999 (dimana UU PTPK mulai diberlakukan), namun sampai dengan tahun 2010 (sekitar 11 tahunan) belum pernah muncul perkara korupsi dimana korporasi dijadikan sebagai terdakwa dan dituntut serta dipidana. Baru dalam perkara PT. GJW yang diajukan sebagai terdakwa oleh Kejaksaan dan dituntut ke pengadilan tindak pidana korupsi.

Pada awalnya PT. GJW ditunjuk oleh Pemerintah Kota Banjarmasin sebagai mitra kerja dalam pelaksanaan kerjasama kontrak bagi tempat usaha untuk pembangunan Pasar Induk Antasari. PT. GJW melalui ST. Widagdo (SW) selaku Diruktur Utama menandatangani nota kerjasama tersebut. Selanjutnya dilakukan adendum kerjasama dimana PT. GJW diwakili oleh Drs. Tjiptomo selaku Direkturnya. Sampai dengan batas waktu yang disepakati penyelesaiannya, pembangunan Pasar Sentra Antasari tersebut tak kunjung selesai, bahkan meskipun diberikan tambahan waktu, tetap tidak terselesaikan juga. Selain itu sesuai dengan adendum, PT. GJW mempunyai kewajiban membayar retribusi, pergantian sewa, dan pelunasan kredit inpres Pasar Antasari yang keseluruhannya berjumlah Rp.6.750.000.000,- (enam milyar tujuh ratus lima puluh juta rupiah), tetapi PT. GJW hanya membayar sebesar Rp.1.000.000.000,- (satu milyar). Sementara kekurangan pembayaran sejumlah Rp.5.750.000.000,- (lima milyar tujuh raturs lima puluh juta) dengan sengaja tidak disetor oleh PT. GJW. Padahal sebelum dilaksanakan pembangunan Pasar Sentra Antasari dan pengelolaannya dilakukan oleh PT. GJW yang pada saat itu masih dalam bentuk pasar tradisional, Pemerintah kota Banjarmasinmenerima hasil retribusi sebesar lebih kurang Rp.800.000.000,(delapan ratus juta) setiap tahunnya, akan tetapi meskipun sudah terbangun pasar modern tetapi malah Pemerintahan kota Banjarmasinkehilangan pendapatan uang hasil dari pengelolaan Pasar Sentra Antasari sebesar Rp.7.650.143.645,- (tujuh milyar enam ratus lima puluh juta seratus empat puluh tiga ribu enam raturs empat puluh lima rupiah).

Atas kerugian tersebut, SW dituntut ke Pengadilan Tipikor dan berdasarkan putusan Pengadilan Negeri Banjarmasin No.908/ Pid.B/2008/PN.Bjm Jo. Putusan Pengadilan Tinggi Banjarmasin No.02/PID.SUS/2009/ 
PT.BJM Jo. Putusan Mahkamah Agung No.936 K/Pid.Sus/2009 dinyatakan bersalah dan dipidana. Setelah putusan pemidanaan terhadap SW berkekuatan hukum tetap, JPU mengajukan PT. GJW selaku korporasi sebagai terdakwa. PT GJW didakwa oleh JPU secara subsidairitas yaitu primair melanggar Pasal 2 ayat 1 jo Pasal 18 jo Pasal 20 Undang- undang Nomor 31 Tahun 1999 sebagaimana telah diubah dan ditambah dengan Undang- undang Nomor 20 Tahun 2001 jo Pasal 64 ayat 1 KUHP dan subsidair melanggar Pasal 3 jo Pasal 18 Undang- undang Nomor 31 Tahun1999, sebagaimana telah di rubah dan ditambah dengan Undang- undang Nomor 21 Tahun 2001 jo 64 ayat 1 KUHP. Dalam tuntutannya, Jaksa Penuntut Umum (JPU) menuntut agar PT GJW dinyatakan telah terbukti bersalah melanggar Pasal 2 ayat (1) jo. Pasal 18 Jo. Pasal 20 Undang-Undang Nomor 31 tahun 1999 tentang Pemberantasan Tindak Pidana Korupsi (UU PTPK) sebagaimana telah diubah dengan Undang undang Nomor 20 tahun 2001 tentang perubahan atas Undang undang Nomor 31 tahun 1999 tentang Pemberantasan Tindak Pidana Korupsi jo . Pasal 64 ayat (1) KUHP sebagaimana dalam Dakwaan Primair, dan menjatuhkan pidana terhadap terdakwa PT GJW dengan pidana denda sebesar Rp.1.300.000.000,(satu milyar tiga ratus juta rupiah) serta pidana tambahan tambahan berupa penutupan sementara PT.GJW selama 6 (enam) bulan.

Berdasarkan tuntutan tersebut, Majelis Hakim Pengadilan Negeri Banjarmasin melalui Putusannya No.812/Pid .Sus /2010 /PN.Bjm memutuskan persis sama dengan tuntutan JPU yaitu menyatakan PT GJW telah terbukti secara sah dan meyakinkan bersalah melakukan tindak pidana korupsi secara berlanjutsebagaimana dalam Dakwaan Primair, karenanya kepada PT GJW dijatuhkan pidana denda sebesar Rp.1.300.000.000,- (satu milyar tiga ratus juta rupiah) serta pidana tambahan tambahan berupa penutupan sementara PT.GJW selama 6 (enam) bulan. Diantara pertimbangan hukum Majelis Hakim Pengadilan Negeri Banjarmasin, diantaranya yaitu :

Bahwa selanjutnya apabila dihubungkan dengan pasal 20 ayat (1) Undang Undang Nomor31 Tahun 1999TentangPemberantasan Tindak Pidana Korupsi sebagaimana telah diubah dengan Undang Undang Nomor 20 tahun 2001 yang berbunyi bahwa dalam hal tindak pidana Korupsi dilakukan oleh atau atas nama suatu Korporasi maka tuntutan dan penjatuhan pidana dapat dilakukan terhadap Korporasi dan atau Pengurusnya, kata dandalam kalimat tersebut menunjukkan bahwa undang-undang mengatur adanya lebih dari satu pelaku yang dapat dikenakan dalam satu tindak pidana Korupsi, yaitu orang/persoon yang menjadi directingmind daripada korporasi tersebut maupunkorporasi itu sendiri yang dalam hal inidiwakili oleh Stevanus Widagdo (SW) selakuDirektur Utamanya, olehkarenanya walaupunterhadap SW telah dinyatakanbersalah dan dijatuhi hukuman atas tindakpidana korupsi namun PT GJW selaku korporasi yang terlibat didalamnyajuga dapat dimintai pertanggungjawaban atas kesalahan/ penyimpangan yang telah dilakukan.

Atas putusanPengadilan Negeri Banjarmasin, terdakwa melalui Penasihat hukumnya mengajukan upaya hukum banding kepada Pengadilan Tinggi Banjarmasin.Pengadilan Tnggi Banjarmasin melalui putusannya Nomor 04/ PID.SUS/201 1/PT.BJM memutuskan menerima permintaan banding dari Penasehat Hukum Terdakwa dan menguatkan Putusan Pengadilan Negeri Banjarmasin Nomor : 812/Pid .Sus /2010 /PN.Bjm tanggal 09 Juni 2011 yang dimintakan banding tersebut, dengan perbaikan sekedar mengenai besarnya denda sehingga untuk selengkapnya berbunyi menyatakan terdakwa PT GJW telah terbukti secara sah dan meyakinkan bersalah melakukan tindak pidana "korupsi secara berlanjut" dan karenanya menjatuhkan kepada terdakwa PT GJW pidana denda sebesar Rp.1.317 .782 .129 ,- (satu milyar tiga ratus tujuh belas juta tujuh ratus delapan puluh dua ribu seratus dua puluh sembilan Rupiah) serta menjatuhkan pidana tambahan berupa Penutupan Sementara PT.GJW selama 6 (enam) bulan. Adapun pertimbangan dari Majelis Hakim diantaranya yaitu:

Menimbang, bahwa dalam perjanjian Kerja Sama Nomor : 664/ I / 548 /Prog - Nomor : 003/GJW/VI I / 1998 tentang Kontrak Bagi Tempat Usaha dalam rangka Pembangunan Pasar Induk Antasari Kota Banjarmasin yang ditandatangani oleh SW Direktur Utama yang dalam hal ini bertindak untuk dan atas nama PT.GJW (Terdakwa), 


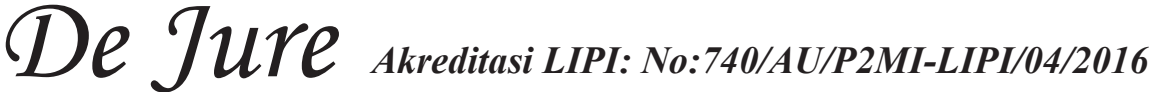

makajelas bahwa tindakan SW tersebutdalam rangka maksud dan tujuan korporasi serta untuk memberikan manfaat bagi korporasi tersebut yaitu PT.GJW (Terdakwa).

Menimbang, bahwa sewaktu masih menjadi pasar tradisional Pemerintah Kota Banjarmasin menerima hasil retribusi dari pasar Antasari sebesar Rp.800.000.000,(delapan ratus juta Rupiah) setiap tahunnya, akan tetapi setelah dibangun menjadi pasar modern Pemerintah Kota Banjarmasin kehilangan uang dari hasil pengelolaan Pasar Sentra Antasari, karena Terdakwa yang ditunjuk sebagai Pengelola Pasar Sentra Antasari mulai tahun 2004 sampai tahun 2007 tidak pernah membayar uang pengelolaan kepada Kas Daerah Pemerintah Kota Banjarmasin, dan menurut laporan keuangan Pengelolaan Pasar Sentra Antasari telah terkumpul dana :

- Tahun 2004 sebesar Rp.1.828.819 .906, -

- Tahun 2005 sebesar Rp.2.421.033 .566 , -

- Tahun 2006 sebesar Rp.1.966.948 .921, -

- Tahun 2007 sebesar Rp.1.433.341 .252, -

Jumlah Rp.7.650.143 .645 , - ( tujuh milyar enam ratus lima puluh juta seratus empat puluh tiga ribu enam ratus empat puluh lima Rupiah), uang sebesar itulah yang tidak disetorkan oleh Terdakwa ke Kas Daerah Pemerintah Kota Banjarmasin

Menimbang, bahwa SW, selaku Direktur Utama PT.GJW berdasarkan putusan Pengadilan Negeri Banjarmasin Nomor: 908/Pid.B/2008 /PN.Bjm tanggal 18 Desember 2009 jo putusan Pengadilan Tinggi Banjarmasin Nomor : 02/Pid .Sus /2009 /PT.BJM, tangga 124 Pebruari 2009, jo putusan Mahkamah Agung Republik Indonesia Nomor : 936.K/Pid .Sus /2009 tanggal 25 Mei 2009 telah dinyatakan bersalah melakukan tindak pidana Korupsi yang dilakukan secara bersama-sama dan berlanjut, dan telah di jatuhi hukuman penjara selama 6 (enam) tahun, serta membayar uang pengganti sebesar Rp.6.332.361.516, - (enam milyar tiga ratus tiga puluh dua juta tiga ratus enam puluh satu ribu lima ratus enam belas Rupiah) sehingga dengan demikian maka masih ada kekurangan/selisih kehilangan uang hasil dari penggelolaan Pasar Sentra
Antasari dengan uang pengganti yang telah dijatuhkan dalam putusan SW sebesar Rp.7.650.143.645, - Rp.6.332.361.516, - = Rp.1.317.782.129, - (satu milyar tiga ratus tujuh belas juta tujuh ratus delapan puluh dua ribu seratus dua puluh sembilan Rupiah)

Menimbang, bahwa uang kekurangan inilah yang menjadi beban serta tanggung jawab yang harus dibayar oleh Terdakwa, dan hal itu sudah sesuai/tidak bertentangan dengan ketentuan Pasal 20 ayat 7 Undangundang Nomor 31 Tahun 1999 yang telah diubah dan ditambah dengan Undang-undang Nomor 20 Tahun 2001 yang menyatakan bahwa pidana pokok yang dapat dijatuhkan terhadap korporasi hanya denda, dengan ketentuan maksimum pidana di tambah $1 / 3$ (satu per tiga).

Terhadap putusan Pengadilan Tinggi Banjarmasin Nomor 04/PID.SUS/201 1/PT.BJM diatas tidak ada upaya hukum Kasasi. Karena setelah diberitahukannya putusan tersebut, Terdakwa PT. GJW sampai dengan batas waktu akhir tidak mengajukan memori Kasasi. Sehingga secara conditio sine quanon putusan ini menjadi berkekuatan hukum tetap (inkracht) dan bisa dieksekusi. Beberapa pertimbangan hukum, baik dari putusan pengadilan tingkat pertama maupun pengadilan tingkat banding dalam perkara PT.GJW ini menarik untuk dianalisis karena mengandung kaidah hukum yang baru dan layak untuk ditinjau dari perspektif hukum progresif sehingga dapat diketahui dan dimaknai nilai progresivitasnya.

Pada konsepsi hukum progresif, para penegak hukum khususnya hakim memegang peran penting dan strategis. Sebagaimana dalam suatu negara hukum (rechtstaat) seperti negara Indonesia, Hakim dalam menegakkan hukum dan keadilan merupakan salah satu sendi dasar yang pokok dan utama (Mulyadi, 2012:54). Mengingat keberadaan undang-undang tidak sempurna maka Hakim harus menafsirkan dan atau menggali kandungan norma yang terdapat di dalam undangundang itu (Pangaribuan, 2009:188). Kekosongan hukum yang terjadi akibat tidak sempuranya undang-undang tersebut akan dapat berubah menjadi kekacauan (Ansyahrul, 2011:134). Oleh karenanya dalam melakukan usaha pencapaian terhadap nilai-nilai keadilan, Hakim diberikan keleluasaan untuk melakukan penafsiranpenafsiran, penemuan-penemuan hukum bahkan 
menurut aliran progresif, Hakim dimungkinkan untuk melakukan penciptaan hukum jika kenyataan telah mengharuskan itu (Witanto \& Kutawaringin, 2013:26).

Pada asasnya, karakteristik dari hukum progresif dapat ditandai dengan pernyataan sebagai berikut (Rahardjo, 2007:233):

1. Hukum ada untuk mengabdi kepada manusia.

2. Hukum progresif akan tetap hidup karena hukum selalu berada pada statusnya sebaga law ini the making dan tidak pernah bersifat statis final, sepanjang manusia itu ada, maka hukum progresif akan terus hidup dalam menata kehidupan masyarakat.

3. Dalam hukum progresif selalu melekat etika dan moralitas kemanusiaan yang sangat kuat, yang akan memberikan respon terhadap perkembangan dan kebutuhan manusia serta mengabdi pada keadilan, kesejahteraan, kemakmuran dan kepedulian terhadap manusia pada umumnya.

Kaidah hukum progresif diatas, tentu juga terkait dengan Hakim dan putusan pengadilan sehingga yang dimaksudkan dengan progresifnya terletak pada aspek penafsiran dan penemuan hukum yang dilakukannya. Ahmad Rifa'i berpendapat bahwa karakteristik penemuan hukum yang progresif adalah (Rifa'i, 2011:48):

1. Penemuan hukum yang didasarkan atas apresiasi hakim sendiri dengan dibimbing oleh pandangan atau pemikirannya secara mandiri, dengan berpijak pada pandangan bahwa hukum itu ada untuk mengabdi kepada manusia.

2. Penemuan hukum yang bersandarkan pada nilai-nilai hukum, kebenaran dan keadilan serta juga etika dan moralitas.

3. Penemuan hukum yang mampu menciptakan nilai-nilai baru dalam kehidupan masyarakat yang sesuai dengan perkembangan zaman dan teknologi serta keadaan masyarakat.

Sebelum menganalisa putusan pemidanaan terhadap PT. GJW dari perspektif penemuan hukum progresif, perlu diapresiasi terlebih dahulu langkah JPU mengajukan PT. GJW sebagai terdakwa tindak pidana korupsi. Karena penemuan hukum dan putusan Hakim yang progresif itu tidaklah mungkin terjadi jika tidak didahului oleh keberanian dan inisiatif Kejaksaan melakukan penuntutan PT. GJW selaku korporasi sebagai terdakwa dalam perkara tindak pidana korupsi. Langkah kejaksaan ini tergolong progresif jika ditinjau dari perspektif bahwa selama perkara PT. GJW diajukan sebagai Terdakwa korupsi, belum ada korporasi yang secara khusus diajukan sebagai Terdakwa korupsi.

Bahkan Komisi Pemberantasan Korupsi (KPK) sampai saat ini belum pernah melakukan penyidikan dan penuntutan terhadap subyekhukum korporasi, khususnya terhadap tindak pidana suap, untuk tindak pidana tersebut, KPK hanya melakukan penyidikan dan penuntutan sebatas pada tindak pidana suap yang tertangkap tangan. Meskipun jika melihat kasus-kasus yang ditangani KPK, terdapat korporasi yang turut bagian dalam tindak pidana suap tersebut. baik dalam sistem peradilan pidana konvensional dan sistem peradilan pidana tindak pidana korupsi, masih mengalami kendala dalam menuntut korporasi sebagai subjek hukum (Budianto, 2012:184). Berkenaan dengan hal ini dapat dikatakan bahwa kejaksaan telah melakukan langkah hukum yang progresif karena belum umum diambil oleh para penegak hukum lainnya yang natabene seringkali mengalami kendala dalam menuntut korporasi sebagai subjek hukum korupsi.

Penempatan PT GJW sebagai Terdakwa adalah tepat, karena meskipun Pasal 20 ayat (1) UU PTPK menyatakan bahwa bilamana terjadi tindak pidana korupsi yang melibatkan korporasi maka pertanggungjawabannya bisa dimintakan kepada pengurus dan/atau wakilnya, akan tetapi apa yang terjadi pada perkara ini, dengan menempatkan pelaku tindak pidananya SW, Orang (pengurus), dan PT GJW, korporasinya, menunjukkan bahwa penempatan korporasi sebagai terdakwa sudah tepat dibandingkan hanya dengan menuntut pelaku individualnya semata. Hal ini dikarenakan dari perkara SW terbukti bahwa SW melakukan apa yang dilarang itu dalam jabatannya sebagai anggota direksi PT GJW, yang dilakukannya untuk kepentingan PT GJW, serta masih dalam ruang lingkup bertindaknya PT GJW (Sjawie, 2015:180). Dalam konteks inilah putusan Pengadilan Negeri Banjarmasin Nomor : 812/Pid .Sus /2010/PN.Bjm tanggal 09 Juni 2011 memutuskan pemidanaan terhadap PT. GJW. 


\section{De Jure Akreditusi LIPI: No:740/AU/P2M-LIPLO42016}

Sebuah kaidah hukum diangkat dan menjadi dasar dalam putusan pemidanaan dari putusan Nomor: 812/Pid .Sus /2010 / PN.Bjm yaitu "walaupun terhadap $S W$ telah dinyatakan bersalah dan dijatuhi hukuman atas tindak pidana korupsi namun PT GJW selaku korporasi yang terlibat didalamnya juga dapat dimintai pertanggungjawaban atas kesalahan/ penyimpangan yang telah dilakukan." Jadi bukan berarti bahwa setelah subjek hukum berupa persoon telah dipidana maka korporasi sebagai sarana untuk mendapatkan keuntungan dari perbuatan korupsinya bisa terbebaskan dari pertanggungjawaban pidana. Apalagi korporasi tersebut mendapatkan keuntungan dan kemanfaatan dari perbuatan subjek hukum persoon tersebut juga. Selama ini seolah terdapat kesan bahwa korporasi yang digunakan sebagai sarana melakukan korupsi, ketika directing mindnya diputus pemidanaannya, maka korporasinya tidak dijerat dan dipertanggungjawabkan secara pidana.

Padahal dalam berbagai kasus korupsi yang melibatkan korporasi sebagai sarana merugikan negara, diantaranya secara jelas mengemukakan keterkaitan pendirian atau pengelolaan korporasi yang bertujuan dan dimaksudkan untuk memperoleh keuntungan dari proyek-proyek pemerintahan yang sengaja dimanipulasi dan dikorupsi dengan berbagai modus operandi.Sayangnya meskipun telah diputus pemidanaan terhadap pengurusnya yang terbukti telah melakukan perbuatan merugikan keuangan negara dan bahkan sampai putusan tersebut berkekuatan hukum tetap, tak kunjung dilakukan proses penuntutan dan pemidanaan terhadap korporasinya. Oleh sebab itu kaidah hukum dari pemidanaan putusan Pengadilan Negeri Banjarmasin ini dapat menjadi preseden yang baik bagi upaya pemberantasan korupsi di negeri ini khususnya terkait dengan efektivitas pemidanaan terhadap korporasi sebagai Pelaku $a$ quo pertanggungjawabannya atas terjadinya tindak pidana korupsi. Jadi begitu pengurusnya yang berposisi sebagai directing mind telah terbukti bersalah melakukan tindak pidana korupsi dan dipidana karenanya sesuai putusan pengadilan yang berkekuatan hukum tetap, maka terhadap korporasinya seharusnya dituntut dan diproses pertanggungjawaban pidananya dihadapan peradilan tindak pidana korupsi.
Selain mengemukakan kaidah hukum yang bernilai baru dan progresif sebagaimana tersebut diatas, putusan pemidanaan dari Pengadilan Negeri Banjarmasin Nomor : 812/Pid .Sus /2010/PN.Bjm yang menjatuhkan pidana sesuai dengan apa yang dituntut oleh JPU ini juga menarik ditinjau dari perspektif hukum progresif. Secara normatif putusan pemidanaan dari Hakim mengacu pada dakwaan a quo tuntutan JPU dan musyawarah Majelis. Namun secara praktik peradilan, umumnya putusan pemidanaan tersebut dibawah tuntutan pidana JPU. Bahkan terdapat kesan yang umum terkait kisaran putusan pemidanaan dari Hakim adalah 2/3 (dua pertiga) dari tuntutan pidana JPU. Hanya dalam kasus-kasus tertentu, Hakim keluar dari "kesan kebiasaan" tersebut dengan memberikan putusan pemidanaan yang selaras dan sesuai dengan yang dimintakan JPU. Dalam perspektif ini dapat dikatakan bahwa perkara korporasi sebagai Terdakwa korupsi ini adalah yang tergolong khusus. Bisa jadi dengan semangat pemberantasan korupsi dan memberikan langkah hukum pengembalian kerugian negara yang sepadan menjadi alasan dasar divonisnya PT. GJW dengan pemidanaan yang sesuai dengan tuntutan pidana JPU. Dalam konteks inilah putusan pemidanaan terhadap PT. GJW oleh Pengadilan Negeri Banjarmasin bernilai progresif.

Selain dari putusan pemidanaan oleh Pengadilan Negeri Banjarmasin Nomor : 812/ Pid .Sus $/ 2010 /$ PN.Bjm, selanjutnya putusan pemidanaan pada tingkat bandingnya yaitu putusan Nomor 04/PID.SUS/201 1/PT.BJM juga memiliki nilai progresivitas dari upaya penemuan hukumnya. Nilai progresivitas itu tercerminkan dalam putusannya yang menambahkan pidana denda terhadap PT. GJW selain yang telah diputuskan oleh Pengadilan Negeri Banjarmasin sebelumnya. Dalam pertimbangan hukumnya, Majelis Hakim Pengadilan Tinggi Banjarmasin berpendapat bahwa "masih ada kekurangan/ selisih kehilangan uang hasil dari penggelolaan Pasar Sentra Antasari dengan uang pengganti yang telah dijatuhkan dalam putusan $S W$ sebesar Rp.7.650.143.645, - Rp.6.332.361.516, - = Rp.1.317.782.129, - (satu milyar tiga ratus tujuh belas juta tujuh ratus delapan puluh dua ribu seratus dua puluh sembilan Rupiah). Karenanya uang kekurangan inilah yang menjadi beban serta tanggung jawab yang harus dibayar oleh Terdakwa PT. GJW". 
Jika putusan pemidanaan dari Pengadilan sebelumnya tergolong progresif dari sisi kesesuaiannya dengan tuntutan JPU, maka selain dengan menguatkan dan membenarkan putusan pengadilan tingkat pertama tersebut, pengadilan tingkat banding memberikan penambahan pidana dendanya dengan sejumlah yang belum ternilai dengan sempurna saat menjatuhkan pidana uang pengganti yang telah dijatuhkan oleh putusan SW. Dari pertimbangan putusan pemidanaan tersebut dapat dimaknai bahwa pengadilan tingkat banding telah memberikan sebuah terobosan hukum yaitu menegaskan korelasi antara perhitungan pemidanaan yang belum sempurna dijatuhkan kepada subjek hukum persoon yang merupakan directing mind korporasi oleh pengadilan terdahulu yang notabene telah inkracht dengan penghitungan denda yang harus ditanggung oleh korporasinya.

Karenanya dipandang relevan menambahkan pidana denda terhadap korporasi dengan suatu jumlah/nilai kerugian negara yang kurangsempurna diperhitungkan dalam pemidanaan terhadap pengurusnya. Dalam konteks ini, nilai progresivitas hukum dari pertimbangan terobosan hukum dalam putusan pemidanaan dariputusan Nomor 04/PID.SUS/201 1/PT.BJM tak terbantahkan. Apalagi dalam perspektif normatif, hal ini tidak diatur secara eksplisit. Hukum positif hanya memberikan acuan bahwa terhadap korporasi dapat dilakukan pemberatan yaitu $1 / 3$ (sepertiga) dari pidananya. Tetapi tidak diatur bahwa kerugian negara yang telah diakibatkan oleh perbuatan korupsi pengurusnya dan telah dijatuhkan pidana berupa uang penggantinya dapat dikorelasikan dengan pidana denda terhadap korporasinya bilamana masih terdapat selisih perhitungan atau kekurangannya.

Secara teoritis, korelasi pembebanan berupa pertanggungjawaban pidana antara korporasi dengan pengurusnya ini telah terakomodasi pada sejumlah teori, khususnya teori agregasi. Bahwa pertanggungjawaban pidana dapat dibebankan kepada badan hukum jika perbuatan tersebut dilakukan oleh sejumlah orang yang memenuhi unsur delik yang mana antara satu dengan yang lain saling terkait dan bukan berdiri sendirisendiri. Maka dalam konteks ini, jika kesatuan pertanggungjawaban pidana diantara keduanya (pengurus dan korporasinya) diakui eksistensinya maka cukup logis dan memenuhi rasionalitas hukum jika pemidanaannya tidak dapat dilepaskan sama sekali atau terpisah dan dipisahkan perhitungannya (khususnya yang terkait dengan penghitungan pengembalian kerugian negara). Meskipun kaidah hukum ini tidak biasa dan belum umum digunakan dalam praktek peradilan karena mengingat acuan normatifnya kurang begitu kokoh dan teorinya juga tidak menjelaskan secara eksplisit, akan tetapi Majelis Hakim dalamputusan Nomor 04/PID.SUS/201 1/PT.BJM ini berani mengambil langkah terobosan hukum dengan mengaitkan selisih kekurangan perhitungan yang dijatuhkan dalam uang pengganti pada putusn pemidanaan terhadap pengurusnya dan kemudian dibebankan pada korporasinya. Jelas ini merupakan penemuan hukum yang progresifkarena mengandung kebaruan serta dapat digunakan sebagai preseden dalam mempidana korporasi pelaku tindak pidana korupsi.

\section{KESIMPULAN}

Meskipun telah lama ditegaskan sebagai salah satu subjek hukum dan dapat dipertanggungjawabkan dalam tindak pidana korupsi tetapi belum pernah muncul perkara korupsi dimana korporasi dijadikan sebagai terdakwa dan dituntut serta dipidana. Baru melalui perkara PT. GJW yang diajukan sebagai terdakwa oleh Kejaksaan dan dituntut ke pengadilan tindak pidana korupsi (setelah SW selaku Direktur Utamanya diputus pemidanaannya dan inkracht di tingkat kasasi).

Kasus PT. GJW merupakan penemuan hukum yang progresif karena mengandung kebaruan dan dapat digunakan sebagai acuan dalam mempidana korporasi pelaku tindak pidana korupsi oleh para Hakim lainnya di kemudian hari.

\section{SARAN}

Pendekatan hukum progresif dapat dijadikan alat analisis menghasilkan kaidah hukum baruyang memfasilitasi terlaksananya tujuan pemidanaan pengembalian kerugian keuangan Negara.

Putusan pemidanaan yang progresif kausus PT. GJW dapat dijadikan sebuah landmark decision dan patut dijadikan acuan para hakim lain di kemudian hari. 


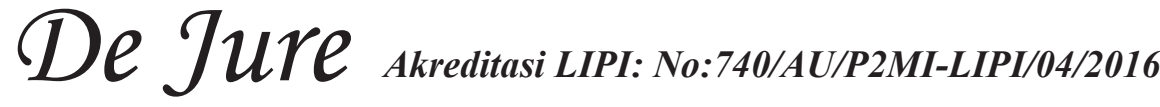

\section{DAFTAR KEPUSTAKAAN}

Ansyahrul, 2011, Pemuliaan Peradilan: dari Dimensi Integritas Hakim, Pengawasan, dan Hukum Acara, Mahkamah Agung, Jakarta, 2011.

Budianto. Agus, Delik Suap Korporasi Di Indonesia,Karya Putra Darwati, Bandung, 2012

Danil. Elwi, Korupsi: Konsep, Tindak Pidana, dan Pemberantasannya, RajaGrafindo Persada, Jakarta, 2012.

Effendy. Marwan, Diskresi, Penemuan Hukum, Korporasi \& Tax Amnesty Dalam Penegakan Hukum, Referensi, Jakarta, 2012.

, Kapita Selekta Hukum Pidana: Perkembangan dan Isu-Isu Aktual dalam Kejahatan Finansial dan Korupsi, Referensi, Jakarta, 2012.

Hiariej.Eddy O.S, Prinsip-Prinsip Hukum Pidana, Cahaya Atma Pustaka, Yogyakarta, 2014

Mas. Marwan, Pemberantasan Tindak Pidana Korupsi, Ghalia Indonesia, Bogor, 2014.

Mulyadi.Lilik, Hukum Acara Pidana Indonesia: Suatu Tinjauan Khusus terhadap Surat Dakwaan, Eksepsi dan Putusan Peradilan, Citra Aditya Bakti, Bandung, 2012.

Pangaribuan.Luhut M.P, Lay Judges \& Hakim Ad Hoc: Suatu Studi Teoritis mengenai Sistem PeradilanPidana Indonesia.Fakultas Hukum Pasca Sarjana Universitas Indonesia \& Papas Sinar Sisanti, Jakarta, 2009.

Priyatno. Dwija, Kebijakan Legislasi Tentang Sistem Pertanggungjawaban Pidana Korporasi Di Indonesia, Utomo, Bandung, 2004.

Rifa'i. Ahmad, Penemuan Hukum Oleh Hakim Dalam Perspektif Hukum Progresif, Jakarta, Sinar Grafika, 2011.

Rahardjo. Satjipto, Membedah Hukum Progresif, Jakarta, Kompas, 2007.

Sintung. Lois, Penuntutan Terhadap Korporasi Sebagai Pelaku Tindak Pidana Suap, Jurnal Lex Crimen, Vol.IV No.1 Jan-Mar 2015
Sjawie. Hasbullah F, Pertanggungjawaban Pidana Korporasi Pada Tindak Pidana Korupsi, Kencana, Jakarta, 2015.

Toruan. Henry Dobald Lbn, Pertanggungjawaban Pidana Korupsi Korporasi, Jurnal Rechtsvinding Volume 3 Nomor 3, Desember 2014.

Witanto. Darmoko Yuti \& Kutawaringin. Arya Putra Negara, Diskresi Hakim: Sebuah Instrumen Menegakkan Keadilan Substantif dalam Perkara-Perkara Pidana, Alfabeta, Bandung, 2013. 